\title{
THE INFLUENCE OF ANIONS ON THE ACTIVITY OF GUSTATORY RECEPTORS
}

\author{
KIYOSHI KUSANO AND MASAYASU SATO* \\ Department of Physiology, University of Kumamoto, College of Medicine, Kumamoto
}

From behaviorial experiments Kionka and Strätz (1922) have concluded that the intensity of salt sensation depends on the cation and that the anion is responsible for its character. This conclusion was supported partly by recent investigations on gustatory receptors, which employed electrophysiological technique (Beidler, 1953; Fishman, 1957), because from the analysis of the magnitude of integrated response or of the frequency of gustatory impulses of single units they have shown that the effectiveness of anions $\left(\mathrm{Cl}, \mathrm{Br}, \mathrm{NO}_{3}, \mathrm{SO}_{4}, \mathrm{CO}_{3}\right)$ did not vary very much whereas the cations $\left(\mathrm{Na}, \mathrm{Li}, \mathrm{NH}_{4}, \mathrm{Ca}, \mathrm{Mg}, \mathrm{K}, \mathrm{Sr}\right.$ and $\mathrm{Ba}$ ) showed a very wide variation in effectiveness. In the preceding paper Kusano and Sato (1957) have also shown that the depressing action of various salts on water response was effected by the cation while most anions had hardly an important role in inhibiting it.

On the other hand there is good evidence showing that various properties of skeletal muscle fibres are modified by anions. The tension, twitch duration and heat production are increased by replacing $\mathrm{Cl}$ in Ringer solution by $\mathrm{Br}, \mathrm{I}$, $\mathrm{NO}_{3}, \mathrm{SCN}$ and $\mathrm{SO}_{4}$ (Hill and Macpherson, 1954; Hill and Howarth, 1957; Kahn and Sandow, 1955; Lubin, 1957), the negative after-potential is increased in its magnitude and duration by substituting $\mathrm{Cl}$ for $\mathrm{Br}, \mathrm{I}, \mathrm{NO}_{3}$ and $\mathrm{SCN}$ (Harris and Martins-Ferreira, 1955; Lubin, 1956), the membrane resistance is increased by $\mathrm{Br}, \mathrm{I}, \mathrm{NO}_{3}, \mathrm{SCN}$ and $\mathrm{SO}_{4}$ (Padsha, 1957) and the resting potential is reduced in nitrate, phosphate and sulphate Ringers while it is not in bromide Ringer (Harris and Martins-Ferreira, 1955; Umezawa, 1957).

Therefore the present experiment was performed in order to investigate (i) whether gustatory receptors in frog's tongue normally respond to various kinds of stimuli immediately after they are immersed in modified Ringer solutions, in which $\mathrm{Cl}$ was replaced by various anions and (ii) whether these anions have some influence on their activity after their being adapted to one of these modified anion-Ringers.

\section{METHOD}

The tongue-glossopharyngeal nerve preparation, isolated from a common Japanese frog (Rana nigromaculata), was mounted in a Perspex chamber composed of two compartments, which are separated by a narrow gap through

Received for publication March 24, 1958.

* 草野 皓, 佐藤昌康 
which the glossophryngeal nerve was passed. These two compartments were filled with Ringer solution and the gap was sealed by petroleum jelly. When the tongue was stimulated with test solution, the Ringer solution in the distal compartment was nearly sucked out.

As stimuli a fixed amount of various taste solutions (about $0.5 \mathrm{cc}$.) was poured over the surface of the tongue from a pipette, which was set over it at a distance of about 3-5 mm., and this was carried out manually and synchronously with each sweep of the oscilloscope. The recording of the afferent impulses in the glossopharyngeal nerve was made from two Ringer pools with a c.r.-coupled amplifier and a single beam oscilloscope.

After a series of experiments were performed with tongue adapted to $\mathrm{Cl}$ Ringer, the solution in the distal pool was replaced by one of modified anionRinger solutions and the response of the tongue adapted to the solution for 30 , 60, 120 minutes and etc. was followed with the similar method employed for normal Ringer. The rinse of the tongue after each stimulation by test solutions was made with the corresponding modified anion-Ringer. The anions investigated were $\mathrm{Br}, \mathrm{I}, \mathrm{NO}_{3}, \mathrm{SCN}, \mathrm{SO}_{4}$ and $\mathrm{H}_{2} \mathrm{PO}_{4}$. Our normal Ringer had the following compositions: $\mathrm{NaCl}, 111 \mathrm{~mm} ; \mathrm{KCl}, 2.5 \mathrm{~mm} ; \mathrm{CaCl}_{2}, 1.08 \mathrm{~mm} ; \mathrm{NaHCO}_{3}$, $2.4 \mathrm{~mm}$. Only all $\mathrm{NaCl}$ was substituted with equimolar (111 $\mathrm{mm}$ ) $\mathrm{NaBr}, \mathrm{NaI}$, $\mathrm{NaNO}_{3}, \mathrm{NaSCN}, \mathrm{Na}_{2} \mathrm{SO}_{4}$ or $\mathrm{NaH}_{2} \mathrm{PO}_{4}$ without changing other compositions. Consequently our sulphate Ringer is equimolar in anions, but in excess of cations to normal Ringer. The $p_{\mathrm{H}}$ of $\mathrm{Cl}$-Ringer was 7.2 , while that of modified anionRinger was $7.3,7.2,7.2,6.2,6.7$ and 5.0 in the order of $\mathrm{Br}, \mathrm{I}, \mathrm{NO}_{3}, \mathrm{SCN}, \mathrm{SO}_{4}$ and $\mathrm{H}_{2} \mathrm{PO}_{4}$. In a few experiments the phosphate Ringer was used, in which $p \mathrm{H}$ was adjusted to 7.4 by adding bicarbonate.

The experiments were performed during autumn under the room temperature of $21-23^{\circ} \mathrm{C}$, and a few additional experiments were carried out during winter with hibernating frogs but under the temperature of about $20^{\circ} \mathrm{C}$.

\section{RESULTS}

Frog's tongue responds to four kinds of taste solutions (salty, sweet, bitter and acid) and distilled water, and sodium salts have an excitatory action on gustatory receptors at a concentration of more than $1 / 16-1 / 8 \mathrm{M}$ while they have a depressing action on water response above $1 / 128 \mathrm{~m}$ (Kusano and Sato, 1957). Therefore two kinds of stimuli were employed in the experiment; one, application of solutions of four taste modalities and the other, sodium salt solutions of various concentrations.

The response pattern of gustatory receptors adapted to Cl-Ringer

The concentration effect of various salts on the whole tongue is shown rather qualitatively in table 1 , which is based on many experiments. However, this varies according to materials, temperature and seasons. It is seen that $\mathrm{KCl}$, $\mathrm{NaCl}, \mathrm{KBr}, \mathrm{NaNO}_{3}$ and $\mathrm{Na}_{2} \mathrm{SO}_{4}$ have a concentration range where water response is depressed and salt discharge is not initiated, while $\mathrm{KNO}_{3}, \mathrm{KI}, \mathrm{NaI}$ and $\mathrm{NaSCN}$ produce weaker discharges over this concentration range. This may be attri- 
buted to the following two alternative possibilities; (i) the latter group has a weaker depressing action on water response than the former and that at the concentration able to depress it they have a stimulating action on salt receptors, or (ii) the latter group has a very low threshold concentration to stimulate salt receptors. $\mathrm{MgCl}_{2}$ have a less ability to inhibit water response than sodium and potassium salts and $\mathrm{CaCl}_{2}$ cannot depress it at all (Kusano and Sato, 1957). $\mathrm{NaH}_{2} \mathrm{PO}_{4}$ has a strong stimulating action, and discharges evoked by $\mathrm{NaH}_{2} \mathrm{PO}_{4}$ solutions of three different concentrations are shown in fig. $3(G, H$ and $I)$. It is of interest that they are all similar regardless the difference of concentrations and that the response magnitude by a $1 / 1024 \mathrm{~m}$ solution is greater than that by distilled water. These strongly suggest that the stimulating action of $\mathrm{NaH}_{2} \mathrm{PO}_{4}$ solutions may come from phosphate ions. It should therefore be stressed here that all the modified anion-Ringers employed in the present experiment have more or less a stimulating action on gustatory receptors adapted to Cl-Ringer.

As a control the response of the tongue to various test solutions was observed for $1 / 2,1,2$ and 3 hours after it being adapted to Cl-Ringer. This is shown in figs. 1 and 2. No appreciable changes in its pattern, magnitude and threshold were observed after 3 hour's adaptation.

TABLE 1. Concentration Effects of Various Salts on the Tongue Adapted to Cl-Ringer

\begin{tabular}{|c|c|c|c|c|c|c|c|c|c|c|c|}
\hline \multirow{2}{*}{$\begin{array}{l}\text { Substances } \\
\text { in Dist. w. }\end{array}$} & \multicolumn{11}{|c|}{ Molar concentration } \\
\hline & $1 / 2$ & $1 / 4$ & $1 / 8$ & $1 / 16$ & $1 / 32$ & $1 / 64$ & $1 / 128$ & $1 / 256$ & $1 / 512$ & $1 / 1,024$ & Dist. w. \\
\hline $\begin{array}{l}\mathrm{KCl} \\
\mathrm{KBr} \\
\mathrm{KNO}_{3} \\
\mathrm{KI} \\
\mathrm{NaCl} \\
\mathrm{NaBr} \cdot 2 \mathrm{H}_{2} \mathrm{O} \\
\mathrm{NaNO}_{3} \\
\mathrm{NaI} \\
\mathrm{NaSCN} \\
\mathrm{NaH}_{2} \mathrm{PO}_{4} \\
\mathrm{Na}_{2} \mathrm{SO}_{4} \\
\mathrm{MgCl}_{2} \cdot 6 \mathrm{H}_{2} \mathrm{O} \\
\mathrm{CaCl}_{2} \cdot 2 \mathrm{H}_{2} \mathrm{O}\end{array}$ & 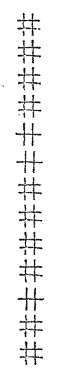 & $\begin{array}{l}+ \\
H \\
H \\
\# \\
+ \\
+ \\
+ \\
+ \\
+ \\
+ \\
+ \\
+ \\
+\end{array}$ & $\begin{array}{l}+ \\
+1 \\
+ \\
+ \\
+ \\
+ \\
+ \\
+ \\
+1 \\
+ \\
+ \\
+\end{array}$ & $\begin{array}{l} \pm \\
+ \\
+ \\
+1 \\
- \\
\pm \\
\pm \\
\pm \\
\pm \\
\# \\
\pm \\
+ \\
\#\end{array}$ & $\begin{array}{l}\overline{1} \\
\dot{1} \\
+ \\
- \\
\overline{-} \\
\pm \\
\pm \\
+1 \\
\frac{1}{H} \\
+\end{array}$ & $\begin{array}{l}\overline{-} \\
\overline{1} \\
\pm \\
- \\
- \\
\overline{1} \\
\overline{1} \\
+ \\
\overline{+} \\
\pm\end{array}$ & $\begin{array}{l} \pm \\
\pm \\
+ \\
+ \\
+ \\
+ \\
+ \\
+ \\
+ \\
+ \\
+ \\
+ \\
+\end{array}$ & $\begin{array}{l}+ \\
+ \\
+ \\
+ \\
+ \\
+ \\
+ \\
+ \\
+ \\
+ \\
+ \\
+ \\
+\end{array}$ & $\begin{array}{l}+1 \\
H \\
+1 \\
+1 \\
+1 \\
+1 \\
+1 \\
H \\
H \\
H \\
H \\
H\end{array}$ & 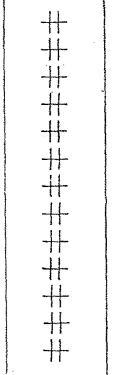 & $\begin{array}{l}H \\
H \\
H \\
H \\
H \\
H \\
H \\
H \\
H \\
H \\
H \\
H\end{array}$ \\
\hline
\end{tabular}

\section{The effect of Br-Ringer}

Responses of the tongue adapted to Br-Ringer are shown in figs. 4, 5 and 6. from which it can be said that Br-Ringer does not modify excitable properties of gustatory receptors drastically. They responded to various taste stimuli as normally as before for about 30 minutes after their adaptation to Br-Ringer, but its effect appeared gradually after 1 hour's adaptation. The general effect of Br-Ringer was to reduce depressing ability of sodium salts on water response and to decrease their stimulating effect of salt receptors (fig. 4 , middle and right columns), but it had little influence on the response of the 

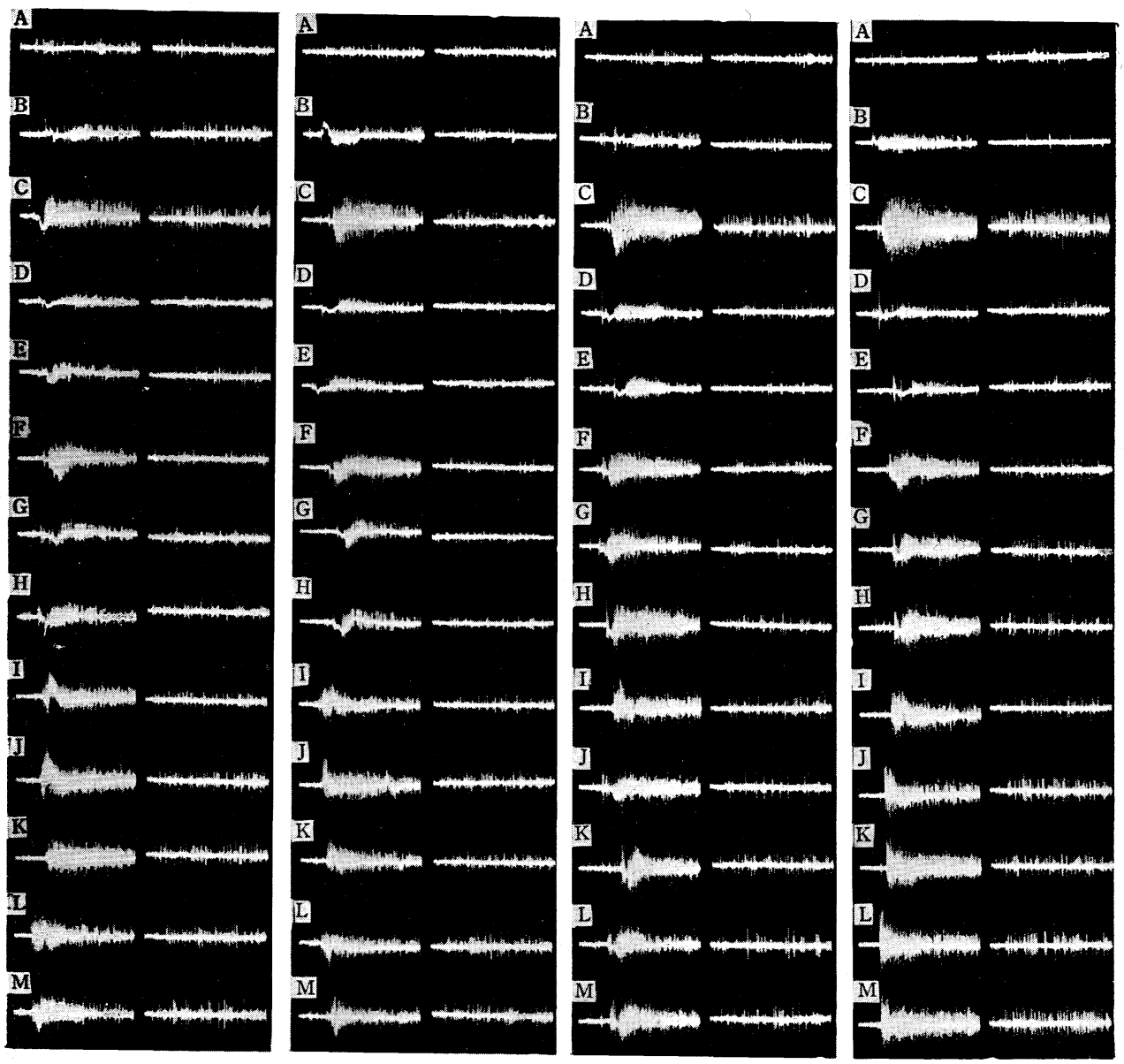

FIG. 1. Response patterns of the tongue adapted to Cl-Ringer. From left: 1/2, 1, 2 and 3 hours after the tongue was immersed in Cl-Ringer. $A$ : spontaneous discharge, $B$ : Cl-Ringer, $C$ : distilled water, $D: 1 / 64 \mathrm{M} \mathrm{NaCl}, E: 1 / 64 \mathrm{M} \mathrm{NaBr}, F: 1 / 64 \mathrm{M} \mathrm{NaNO}_{3}$, $G: 1 / 64 \mathrm{~m}$ NaI, $H: 1 / 64 \mathrm{~m}$ NaSCN, $I: 1 / 4 \mathrm{M} \mathrm{NaCl}, J: 1 / 4 \mathrm{M} \mathrm{NaBr}, K: 1 / 4 \mathrm{M} \mathrm{NaNO}, L$ : 1/4 M NaI, $M: 1 / 4 \mathrm{M} \mathrm{NaSCN}$. Time signal: $10 \mathrm{msec}$. Two successive traces in each frame show photographs taken at the beginning of the discharge and at approximately $5 \mathrm{sec}$ after, showing the rate of its adaptation.

receptors to sucrose, quinine and acid solutions after 1 hour's adaptation (fig. 6). Finally after $3-4$ hour's immersinon in Br-Ringer their response magnitude to both salt solutions and other types of taste solutions were reduced (figs. 5 and 6 ). The threshold of sodium salts for exciting salt receptors and for depressing water response was also raised in parallel to the decrease in response magnitude (table 2), but the excitatory action of $\mathrm{CaCl}_{2}$ and $\mathrm{MgCl}_{2}$ was relatively unaffected. The lowering of the sensitivity to distilled water was relatively 

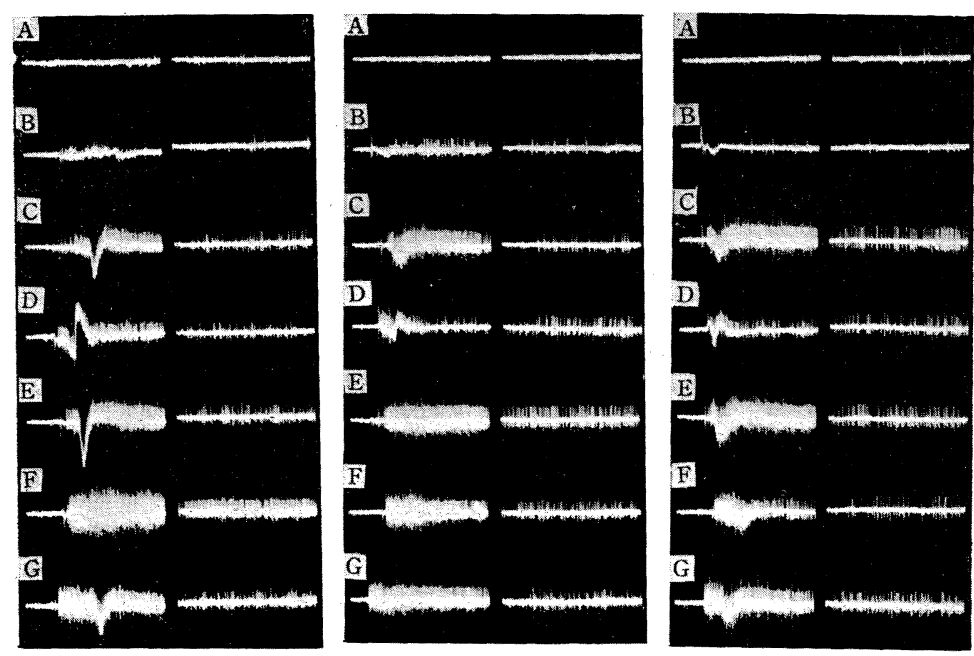

FIG. 2. Response patterns of the tongue adapted to Cl-Ringer. From left: $1 / 2,1$ and 2 hours after the tongue was immersed in Cl-Ringer. $A$ : spontaneous discharge, $B$ : Cl-Ringer, $C$ : distilled water, $D: 1 / 4 \mathrm{M} \mathrm{NaCl}, E: 1 / 4 \mathrm{M}$ sucrose, $F 1 / 256 \mathrm{M}$ hydrochloric quinine, $G: 1 / 64 \mathrm{~N}$ acetic acid. Time signal: $10 \mathrm{msec}$.
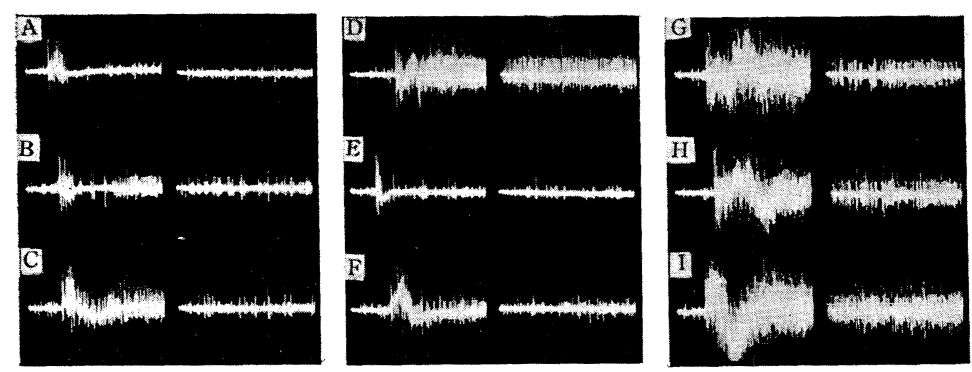

Hincheres

FIG. 3. Response patterns of the tongue to various sodium salts. $A$ : Cl-Ringer, $B$ : $1 / 64 \mathrm{M} \mathrm{NaCl}, C: 1 / 4 \mathrm{M} \mathrm{NaCl}, D$ : distilled water, $E: 1 / 64 \mathrm{M} \mathrm{Na}_{2} \mathrm{SO}_{4}, F: 1 / 4 \mathrm{M} \mathrm{Na}_{2} \mathrm{SO}_{4}, G$ : 1/1,024 M NaH $2 \mathrm{PO}_{4}, H: 1 / 64 \mathrm{M} \mathrm{NaH}_{2} \mathrm{PO}_{4}, I: 1 / 4 \mathrm{M} \mathrm{NaH} \mathrm{PO}_{4}$. Time: $10 \mathrm{msec}$.

small compared with that to sodium salts and, therefore, after the response to sodium salts was reduced markedly, the receptors still responded to distilled water. Four or five hours after the tongue being adapted to Br-Ringer its response became so small that individual spikes could be identified, and in fig. 5 , $J, K, L$ and $M$ of the right column it will be seen that the spike magnitude is larger in water response ("water fibre") than in salt response ("salt fibre") indicating the responses of different fibre types or receptor units (Cohen et al., 1955). 

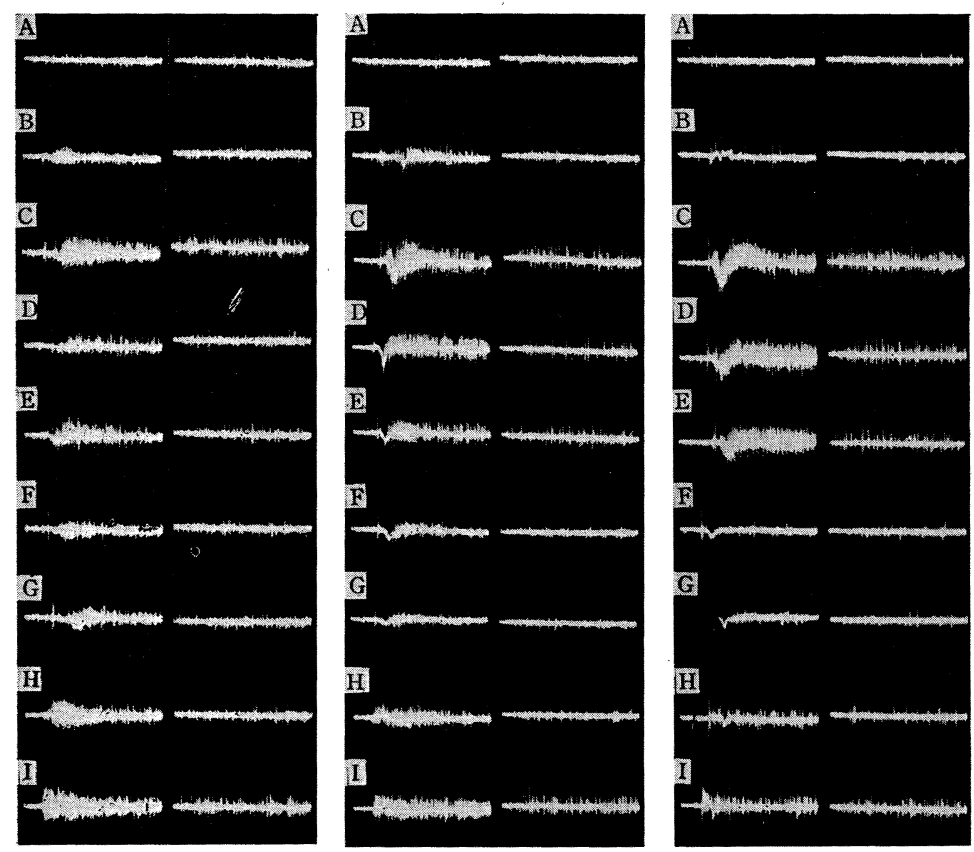

FIG. 4. Response patterns of the tongue adapted to Br-Ringer. From left: adapted to $\mathrm{Cl}$-Ringer for 30 minutes and 1 and 2 hours after the tongue being immersed in $\mathrm{Br}$ Ringer. $A$ : spontaneous discharge, $B$ : Cl-Ringer (left) and Br-Ringer (middle and right), $C$ : distilled water, $D: 1 / 1,024 \mathrm{M} \mathrm{NaCl}, E: 1 / 1,024 \mathrm{M} \mathrm{NaBr}, F: 1 / 64 \mathrm{M} \mathrm{NaCl}, G$ : $1 / 64 \mathrm{M} \mathrm{NaBr}, H: 1 / 4 \mathrm{M} \mathrm{NaCl}, I: 1 / 4 \mathrm{M} \mathrm{NaBr}$. Time signal: $10 \mathrm{msec}$.

\section{The effect of $\mathrm{NO}_{3}$-Ringer}

The tongue hardly showed appreciable changes in its response to various test solutions after its being adapted to $\mathrm{NO}_{3}$-Ringer for less than 30 minutes, but after its adaptation for more than 1 hour nitrate produced fairly drastically similar changes in the response of gustatory receptors to those by bromide. This can be seen in figs. 7 and 8 , in the latter of which it is shown that after the adaptation of the tongue to $\mathrm{NO}_{3}$ - Ringer the response to $1 / 4 \mathrm{M} \mathrm{NaCl}$ is reduced more prominently than the response to sucrose, quinine and acid. Lowering of the sensitivity to distilled water is hardly affected after 1 hour's adaptation. Because of this the receptor units responding to $1 / 64 \mathrm{M} \mathrm{NaCl}$ and $\mathrm{NaNO}_{3}$ are not the same in $F$ and $G$ of the left column (Cl-Ringer) and of the middle $\left(\mathrm{NO}_{3}\right.$-Ringer); the former being the so-called salt fibres and the latter water fibres (Cohen et al., 1955). There seems that some water fibres also respond to $1 / 4 \mathrm{M} \mathrm{NaCl}$ and $\mathrm{NaNO}_{3}$ ( $H$ and $I$ of the middle column). It is therefore clear that nitrate reduces both the depressing action of sodium salts on water response and their excitatory actions on salt receptors. Consequently, the tongue adapted to $\mathrm{NO}_{3}$-Ringer responds to $\mathrm{NaCl}$ solutions of any concentrations (table 

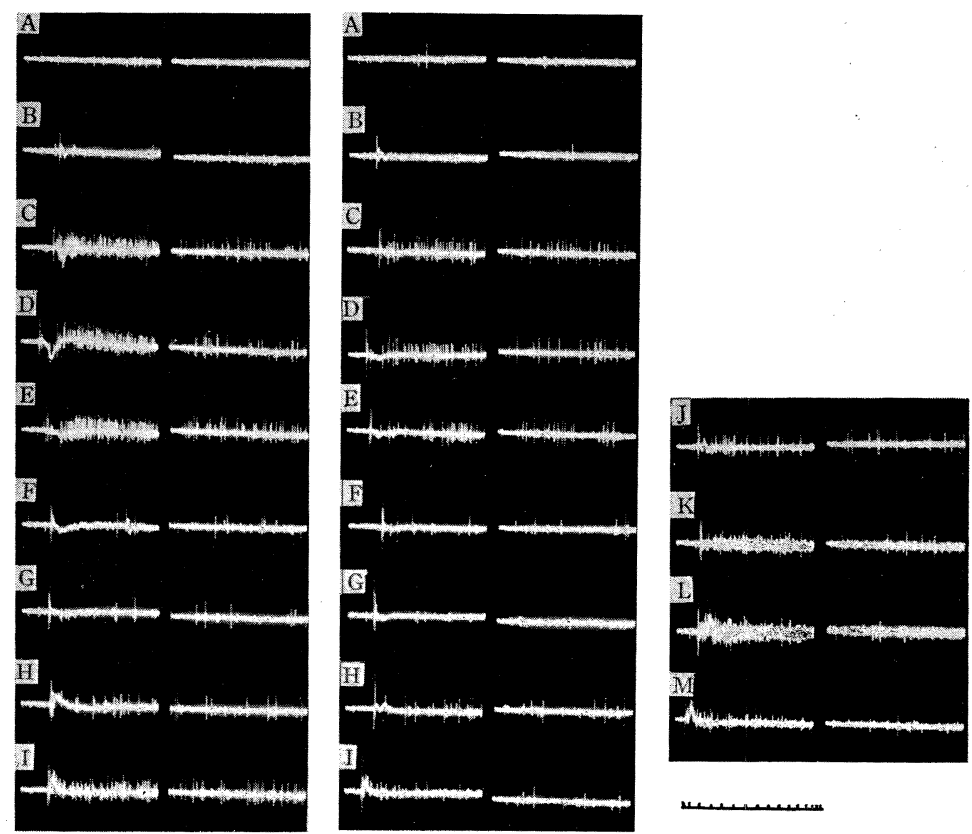

FIG. 5. Response patterns of the tongue adapted to Br-Ringer (continued to fig. 3 ). From left: 3 and 4 hours after the tongue was adapted to Br-Ringer and four frames in right column being taken immediately after those in middle column. Explanations for $A$ to $I$ are the same as those in fig. $4 . \quad J$ : distilled water, $K: 1 / 64 \mathrm{M}$ $\mathrm{CaCl}_{2}, L: 1 / 4 \mathrm{M} \mathrm{CaCl}_{2}$ and $M: 1 / 2 \mathrm{M} \mathrm{NaCl}$.

2). After 2 hour's adaptation to $\mathrm{NO}_{3}$-Ringer the tongue nearly lost its excitability to salt solutions, but still preserved its sensitivity to distilled water, sucrose, quinine and acid. In $J$ and $K$ of fig. 7 the response to a $1 / 4 \mathrm{~m}$ sucrose solution and sucrose in Ringer solution obtained at the final stage of our experiment is shown; the latter being impulses from the sweet fibres (Kusano and Sato 1957) and the former being the mixture of impulses from water fibres (larger spikes) and from sweet fibres (smaller spikes).

\section{The effect of I-Ringer}

The effectiveness of iodide ions stands between bromide and nitrate. IRinger had relatively little effect on gustatory receptors within 2 hours, but the general tendency of its action is more or less the same as $\mathrm{Br}$ - and $\mathrm{NO}_{3^{-}}$ Ringers. After 2 hour's adaptation of the tongue to I-Ringer response magnitude to sodium salts was reduced more prominently than those to other test solutions and their depressing threshold on water response was raised (table 2 ). This can be seen in figs. 9 and 10 , in which the response to $1 / 4 \mathrm{M}$ solutions of $\mathrm{NaCl}$ and $\mathrm{NaI}$ is smaller after 2 hour's adaptation to I-Ringer than that obtained for $\mathrm{Cl}$-Ringer, while the response to $1 / 64 \mathrm{~m}$ solutions is a little greater in the former case than in the latter ( $F$ in the right column) or not very much different ( $G$ of the same column). This simply results from the decrease 

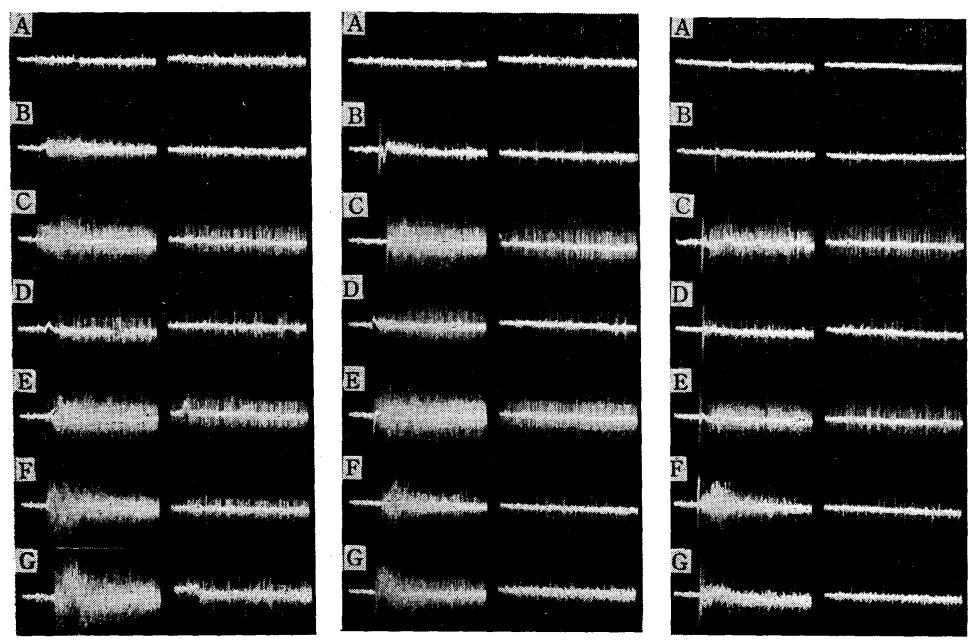

FIG. 6. Response patterns of the tongue adapted to Br-Ringer. From left: adapted to $\mathrm{Cl}$-Ringer for 30 minutes and 1 and 2 hours after the tongue was immersed in $\mathrm{Br}$ Ringer. $A$ : spontaneous discharge, $B$ : Cl-Ringer (left) and Br-Ringer (middle and right columns), $C$ : distilled water, $D: 1 / 4 \mathrm{M} \mathrm{NaCl}, E: 1 / 4 \mathrm{M}$ sucrose, $F: 1 / 256 \mathrm{M}$ hydrochloric quinine, $G: 1 / 64 \mathrm{~N}$ acetic acid. Time: $10 \mathrm{msec}$.

TABLE 2. Concentration Effects of Various Salts on the Tongue Adapted to Br-Ringer (A), $\mathrm{NO}_{3}$-Ringer (B) and I-Ringer (C)

\begin{tabular}{|c|c|c|c|c|c|c|c|c|c|c|c|}
\hline \multirow{2}{*}{$\begin{array}{l}\text { Substance } \\
\text { in Dist. w. }\end{array}$} & \multicolumn{11}{|c|}{ Molar concentration } \\
\hline & $1 / 2$ & $1 / 4$ & $1 / 8$ & $1 / 16$ & $1 / 32$ & $1 / 64$ & $1 / 128$ & $1 / 256$ & $1 / 512$ & $|1 / 1,024|$ & Dist. w. \\
\hline \multicolumn{12}{|l|}{ (A) } \\
\hline $\begin{array}{l}\mathrm{KCl} \\
\mathrm{NaCl} \\
\mathrm{NaBr} \cdot 2 \mathrm{H}_{2} \mathrm{O} \\
\mathrm{NaI} \\
\mathrm{MgCl}_{2} \cdot 6 \mathrm{H}_{2} \mathrm{O} \\
\mathrm{CaCl}_{2} \cdot 2 \mathrm{H}_{2} \mathrm{O}\end{array}$ & $\begin{array}{l}+ \\
+ \\
+1 \\
+ \\
+ \\
+\end{array}$ & $\begin{array}{l}1 \\
- \\
+ \\
+ \\
+ \\
+\end{array}$ & $\begin{array}{l} \pm \\
- \\
\pm \\
+ \\
+ \\
+1\end{array}$ & $\begin{array}{l}- \\
- \\
- \\
\perp \\
\pm \\
\text { 泣 }\end{array}$ & $\begin{array}{l}\perp \\
- \\
\perp \\
\perp \\
H \\
H\end{array}$ & $\begin{array}{l}\perp \\
\perp \\
\perp \\
+ \\
+ \\
+1\end{array}$ & $\begin{array}{l}+ \\
+ \\
+ \\
+ \\
+ \\
+\end{array}$ & $\begin{array}{l}+1 \\
+1 \\
+1 \\
+1 \\
+1 \\
+1\end{array}$ & $\begin{array}{l}+ \\
+ \\
+ \\
H \\
H \\
H \\
H\end{array}$ & $\begin{array}{l}H \\
H \\
H \\
H \\
H \\
H\end{array}$ & 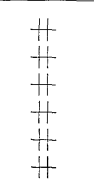 \\
\hline \multicolumn{12}{|l|}{ (B) } \\
\hline $\begin{array}{l}\mathrm{NaCl} \\
\mathrm{NaNO}_{3}\end{array}$ & $\begin{array}{l}+ \\
+\end{array}$ & + & $\perp$ & $\perp$ & $\stackrel{\perp}{+}$ & $\begin{array}{l}+ \\
+\end{array}$ & $\begin{array}{l}+ \\
+\end{array}$ & $\begin{array}{l}+1 \\
+1\end{array}$ & $\begin{array}{l}H \\
H\end{array}$ & + & $\frac{H}{1+}$ \\
\hline \multicolumn{12}{|l|}{ (C) } \\
\hline $\begin{array}{l}\mathrm{KI} \\
\mathrm{NaCl} \\
\mathrm{MgCl}_{2} \cdot 6 \mathrm{H}_{2} \mathrm{O} \\
\mathrm{CaCl}_{2} \cdot 2 \mathrm{H}_{2} \mathrm{O}\end{array}$ & $\begin{array}{l}+ \\
+ \\
+ \\
+\end{array}$ & $\begin{array}{l}+ \\
+ \\
\# \\
\#\end{array}$ & $\begin{array}{l}+1 \\
\perp \\
\text { 将 } \\
\text { 㛙 }\end{array}$ & $\begin{array}{l}+ \\
\pm \\
\# \\
\#\end{array}$ & $\begin{array}{l}\perp \\
+ \\
+ \\
+\end{array}$ & $\begin{array}{l}+ \\
+ \\
+ \\
+\end{array}$ & $\begin{array}{l}+ \\
+1 \\
+ \\
+\end{array}$ & $\begin{array}{l}H \\
H \\
H \\
H\end{array}$ & $\begin{array}{l}H \\
H \\
H \\
H\end{array}$ & $\begin{array}{l}H \\
H \\
H \\
H\end{array}$ & $\begin{array}{l}H \\
H \\
H \\
H\end{array}$ \\
\hline
\end{tabular}



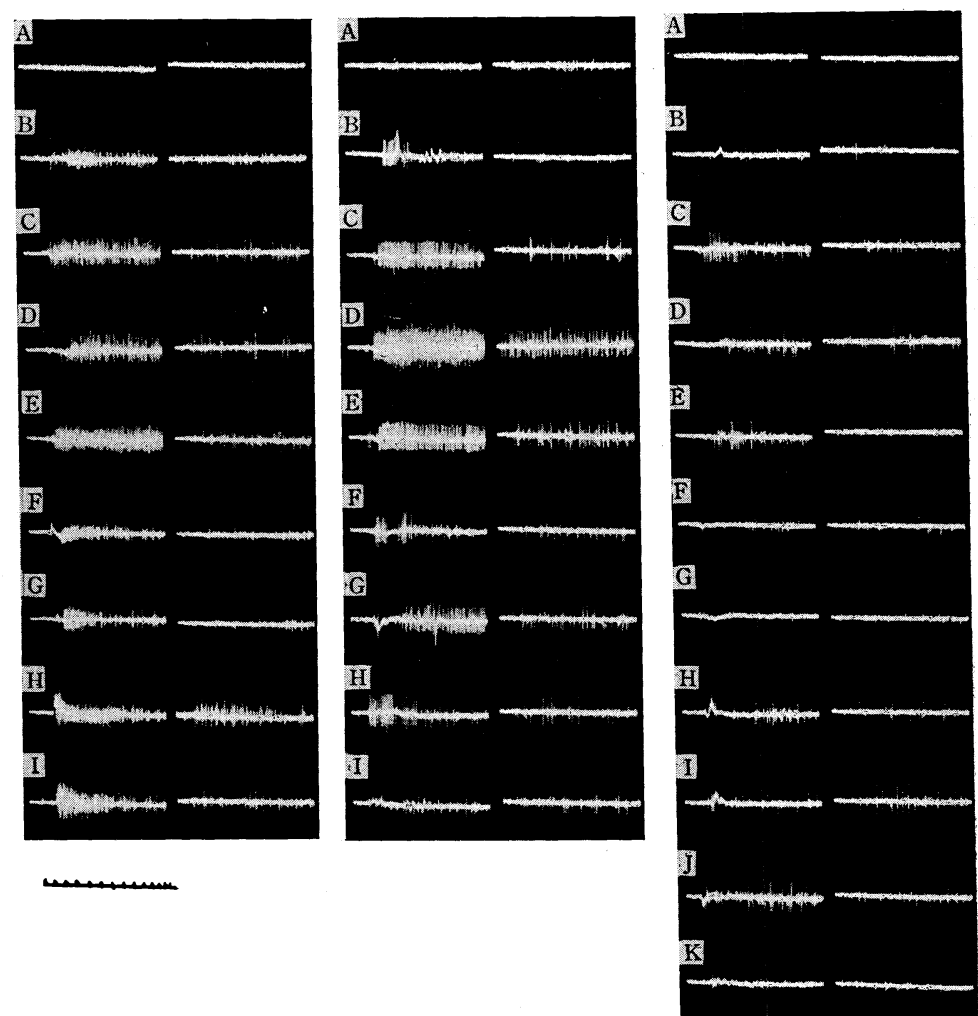

EIG. 7. Response patterns of the tongue adapted to $\mathrm{NO}_{3}$-Ringer. From left: adapted to Cl-Ringer for 30 minutes and 1 and 2 hours after it was immersed in $\mathrm{NO}_{3}$ - Ringer. $A$ : spontaneous discharge, $B$ : Cl-Ringer (left) and $\mathrm{NO}_{3}$-Ringer (middle and right), $C$ : distilled water, $D: 1 / 1,024 \mathrm{M} \mathrm{NaCl}, E: 1 / 1,024 \mathrm{M} \mathrm{NaNO}_{3}, J: 1 / 4 \mathrm{M}$ sucrose in distilled water, $K: 1 / 4 \mathrm{M}$ sucrose in Ringer. Time: $10 \mathrm{msec}$.

in the depressing action of sodium salts on water response. The response to $\mathrm{MgCl}_{2}$ and $\mathrm{CaCl}_{2}$ was not much influenced by iodide (table 2). However, in the long run the sensitivity of the tongue to all kinds of stimuli was reduced.

Gustatory receptors did not show a complete recovery in their response after they, adapted to I-Ringer for more than 2 hours, were restored to normal Ringer (4th column of fig. 10). This irreversibility in the effects was also observed for $\mathrm{Br}-, \mathrm{NO}_{3}$ - and $\mathrm{SCN}$-Ringer solutions.

\section{The effect of SCN-Ringer}

Among monovalent anions thiocyanate ions had the strongest effect on the activity of gustatory receptors. The tongue immersed in SCN-Ringer for more than one and half hours showed spontaneous discharges and the spike magnitude was reduced. This made our experiment difficult in following changes in the response pattern and the threshold of gustatory receptors for a long time, but it was found that the general effect of SCN was more or less the same as 

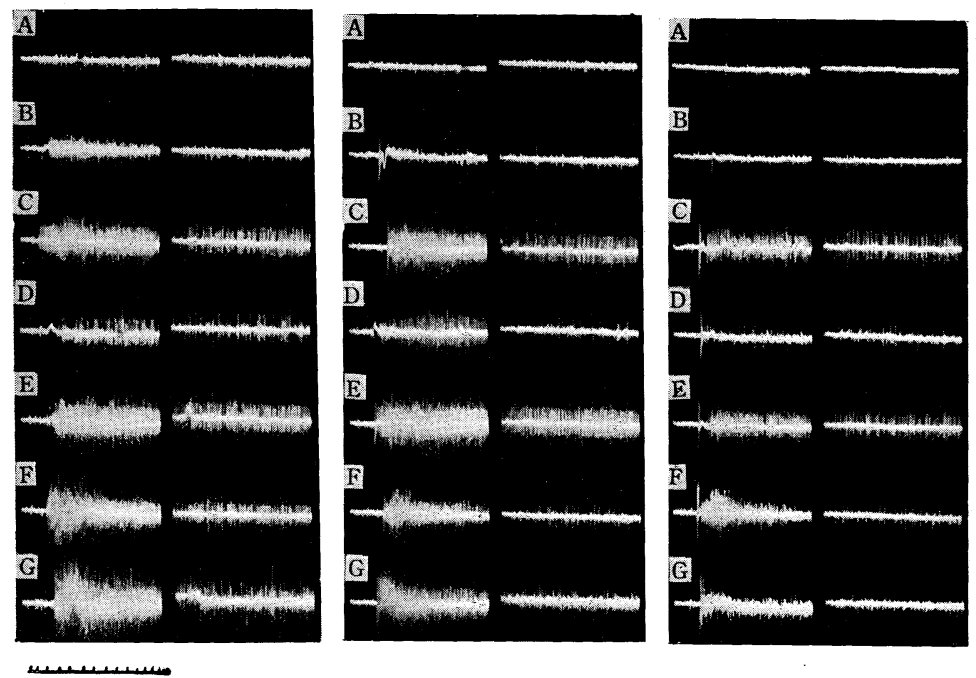

FIG. 8. Response patterns of the tongue adapted to $\mathrm{NO}_{3}$-Ringer. From left: adapted to $\mathrm{Cl}$-Ringer for 30 minutes and 1 and 2 hours after the tongue being immersed in $\mathrm{NO}_{3}$-Ringer. $A$ : spontaneous discharge, $B$ : Cl-Ringer (left) and $\mathrm{NO}_{3}$-Ringer (middle and right), $C$ : distilled water, $D: 1 / 4 \mathrm{M} \mathrm{NaCl}, E: 1 / 4 \mathrm{M}$ sucrose, $F: 1 / 256 \mathrm{M}$ hydrochloric quinine, $G: 1 / 64 \mathrm{~N}$ acetic acid. Time signal: $10 \mathrm{msec}$.

that of the other three anions. It raised the excitatory threshold of sodium salts for salt receptors and reduced the response magnitude, while their threshold concentration for depressing water response was increased by SCN. The sensitivity of the tongue to sucrose, quinine and acid solutions was not very much modified within 1 hour's adaptation (fig. 12). However, it will be seen in figs. 11 and 12 the tongue adapted to SCN-Ringer for 1 hour showed slower adaptation to the taste stimuli (fig. 11, middle column) and augmented response to distilled water (figs. 11 and $12 \mathrm{D}$, right). These may be related to the effect of thiocyanate ions for initiating a spontaneous discharge. The activity of salt fibres was nearly abolished after two hour's adaptation to SCN-Ringer (fig. 11, right column). Between $D$ and $E$ in the right column of fig. 11 about 30 minutes were elapsed, during which the spike magnitude became smaller and the response magnitude was reduced.

\section{The effect of $\mathrm{H}_{2} \mathrm{PO}_{4}$-Ringer}

$\mathrm{NaH}_{2} \mathrm{PO}_{4}$ had a marked stimulating effect in that it initiated more massive discharges at any concentrations than distilled water (fig. 3 and table 1). Therefore $\mathrm{H}_{2} \mathrm{PO}_{4}$-Ringer produced a massive discharge, which subsided very slowly (fig. $13 C$ and $I$, left) and 30 minutes after the tongue had been immersed in $\mathrm{H}_{2} \mathrm{PO}_{4}$-Ringer nearly all the responses to every kind of taste stimuli were abolished. The possibility whether this strong and persistent discharge by $\mathrm{H}_{2} \mathrm{PO}_{4}$-Ringer and its later paralysing action were attributable to its acidity $(p \mathrm{H}, 4.9)$ was investigated by repeating the experiment with the $\mathrm{H}_{2} \mathrm{PO}_{4}$-Ringer, 

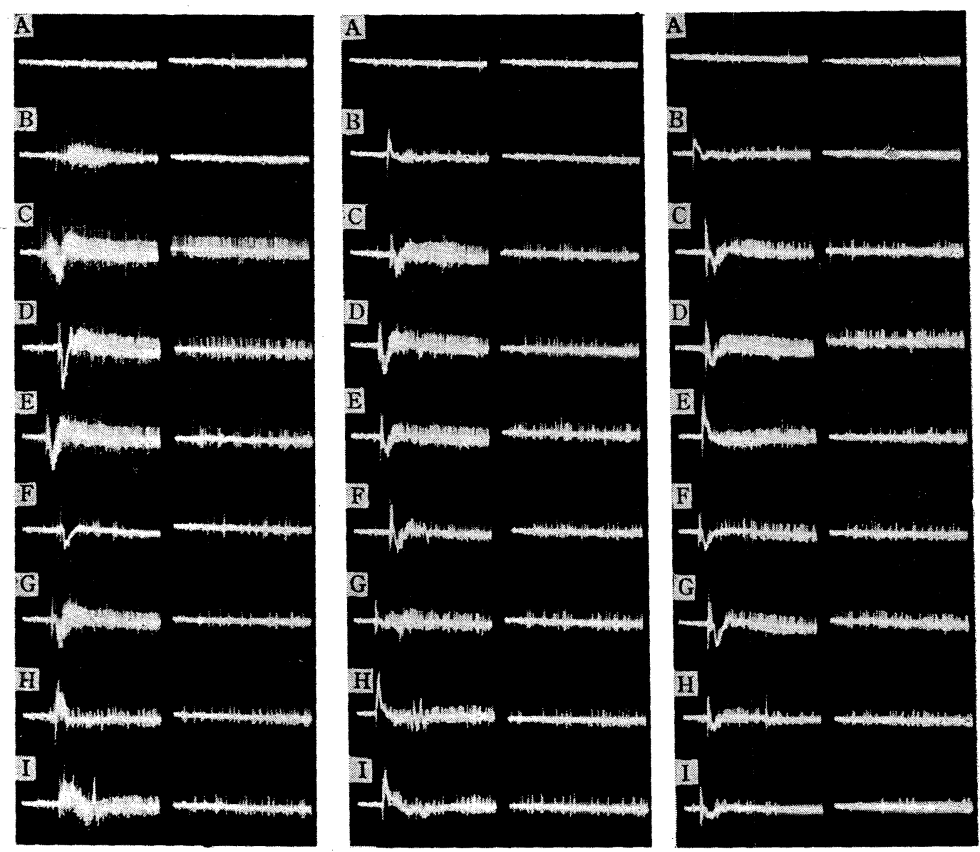

FIG. 9. Response patterns of the tongue adapted to I-Ringer. From left: adapted to Cl-Ringer for 30 minutes, and 1 and 2 hours after the tongue being immersed in I-Ringer. $A$ : spontaneous discharge, $B:$ Cl-Ringer (left) and I-Ringer (middle and right), $C$ : distilled water, $D: 1 / 1,024 \mathrm{M} \mathrm{NaCl}, E: 1 / 1,024 \mathrm{M} \mathrm{NaI}, F: 1 / 64 \mathrm{M} \mathrm{NaCl}, G$ : 1/64 M NaI, $H: 1 / 4 \mathrm{M} \mathrm{NaCl}, I: 1 / 4 \mathrm{M} \mathrm{NaI}$. Time: $10 \mathrm{msec}$.

which was made neutral $(p \mathrm{H}, 7.4)$ by adding sodium bicarbonate to the original solution. Although the neutral phosphate Ringer still produced massive diucharges, their adaptation was rapid, and the tongue immersed in the solution for 30 minutes showed better responses to some of the taste stimuli. Therefore the paralysing action of phosphate Ringer can partly be explained by its acidity, but not completely. One of the interesting phenomena observed with phosphate Ringer is that the sensitivity of the tongue immersed in the solution for 1 hour was nearly, but not wholly, restored to the original level after its being transferred into normal Ringer (right column of fig. 13). Another interesting effect of phosphate Ringer is that it has relatively a small infuence on the sensitivity of the tongue to hydrochloric quinine ( $G$ in the middle column of fig. 13).

The effect of $\mathrm{SO}_{4}$-Ringer

The effect of sulphate Ringer is very interesting and quite different from that of other anion-Ringers, because the tongue hardly showed any changes in its sensitivity and in the magnitude of its response to every kind of taste stimuli after it was immersed in sulphate Ringer for a long time (figs. 14 and 15). In fig. 14 the magnitude of the response of the tongue, immersed in sulphate 

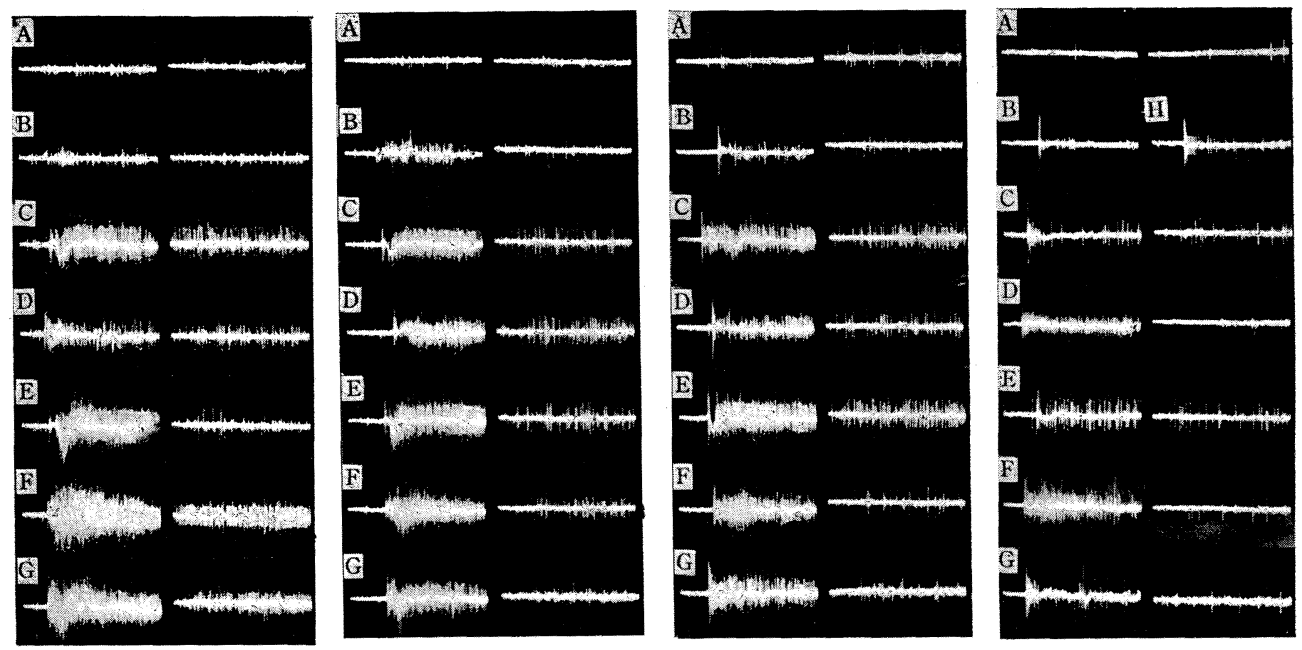

FIG. 10. Response patterns of the tongue adapted to I-Ringer. From left: adapted to Cl-Ringer for 30 minutes, 1 and 2 hours after it being immersed in I-Ringer and 30 minutes after it being transferred into Cl- Ringer. $A$ : spontaneous discharge, $B$ : Cl-Ringer (1st and 4th columns) and I-Ringer (2nd and 3rd columns), $C$ : distilled water, $D: 1 / 4 \mathrm{M} \mathrm{NaCl}, E: 1 / 4 \mathrm{M}$ sucrose, $F: 1 / 256 \mathrm{M}$ hydrochloric quinine, $G: 1 / 64 \mathrm{~N}$ acetic acid, $H$ : I-Ringer. Time signal: $10 \mathrm{msec}$.

Ringer, to distilled water is slightly augmented, though this is not particularly observed in fig. 15 ( 2 nd and 3 rd column, D), and the adaptation of water response is faster in sulphate Ringer than in normal Ringer. It is of interest to note that sulphate Ringer has a stimulating action on the tongue adapted to chloride Ringer, while chloride Ringer provoked a weak discharge from the tongue adapted to sulphate Ringer ( $B$ and $C$ in figs. 14 and $15, I$ in fig. 15). From fig. 14 it is also clear that $\mathrm{Na}_{2} \mathrm{SO}_{4}$ has nearly the same stimulating effect on the tongue to $\mathrm{NaCl}$ (also see table 1). The tongue immersed in sulphate Ringer for 2 hours showed much the same sensitivity to every kind of taste stimuli after it was transferred into normal Ringer (fig. 15). These results mentioned above indicate that sulphate is the only ion, which is inert to gustatory receptors and by which chloride ions can be replaced.

\section{DISCUSSION}

Changes in the receptor activity in the presence of anions

When Cl-Ringer bathing the tongue is replaced by a modified anion-Ringer, the penetration of the anions into the tongue may be divided into three successive stages. First, chloride ions in the extracellular space of the tongue is substituded for the anions used; the equilibrium of this process would be attained quite readily, probably within a minute (Beidler, 1953), because (i) most ions should be freely accessible to the outside of the gustatory cells, (ii) the 

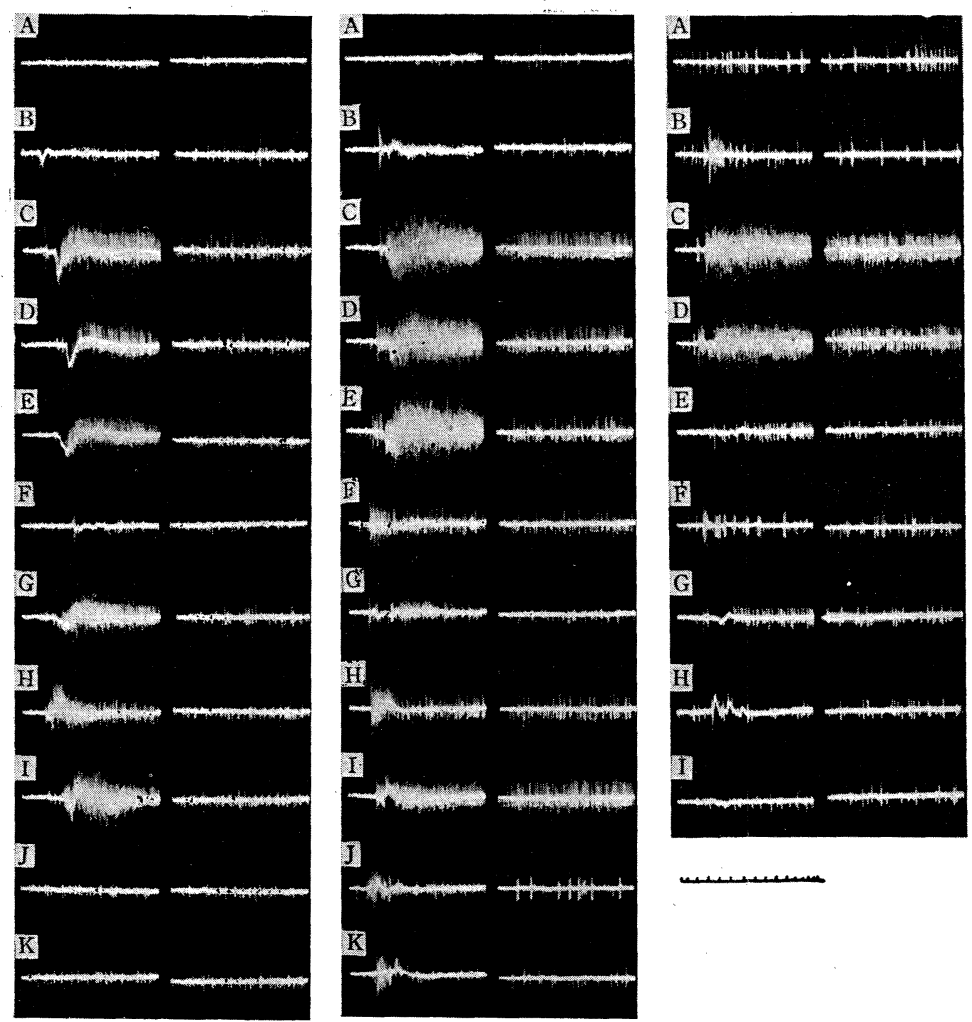

FIG. 11. Response patterns of the tongue adapted to SCN-Ringer. From left: adapted to Cl-Ringer for 30 minutes and 1 and 2 hours after it being immersed in SCNRinger. $A$ : spontaneous discharge, $B: \mathrm{Cl}$-Ringer (left) and SCN-Ringer (middle and right), $C$ : distilled water, $D: 1 / 1,024 \mathrm{M} \mathrm{NaCl}, E: 1 / 1,024 \mathrm{M} \mathrm{NaSCN}, F: 1 / 64 \mathrm{M} \mathrm{NaCl}$, $G: 1 / 64 \mathrm{M} \mathrm{NaSCN}, H: 1 / 4 \mathrm{M} \mathrm{NaCl}, I: 1 / 4 \mathrm{M} \mathrm{NaSCN}, J$ (left column): spontaneous discharges before replacing $\mathrm{Cl}$-Ringer by SCN-Ringer, $K$ (left): discharge after replacing the former by the latter, $J$ (middle): Cl-Ringer, $K$ (middle): SCN-Ringer. Time: 10 msec.

frog tongue is fairly thin, about a thickness of $2 \mathrm{~mm}$. and (iii) gustatory cells with their hairs are situated at the depth of less than about 10-20 $\mu$ from the surface (Kusano and Sato, 1957). Second, the anions should react with the membrane of gustatory receptors and modify its properties. Third, anions may either enter into the cells according to their ease with which they penetrate the membrane and transfer with intracellular $\mathrm{Cl}$, or may change cellular contents of main cations, $\mathrm{K}$.

Most experimental results described above indicate that the tongue does hardly show appreciable changes in its response pattern and in its threshold to various taste solutions within 30 minutes after $\mathrm{Cl}$ was substituted for one of various anions except for phosphate ions. During this period only the first process of anion exchange probably takes place, and therefore our results are con- 

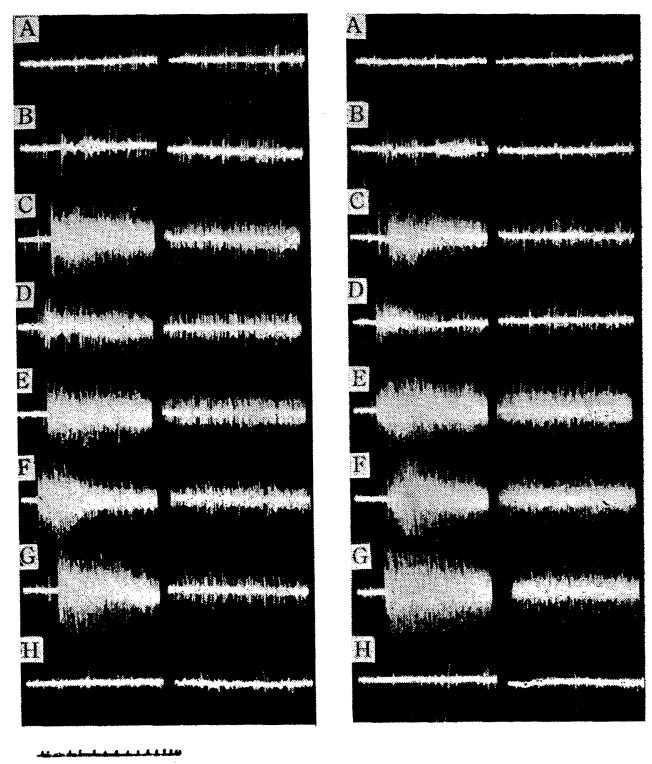

FIG. 12. Response patterns of the tongue adapted to SCN-Ringer. Left: adapted to Cl-Ringer for 1 hour and right: immersed in SCN-Ringer for 1 hour. $A$ : spontaneous discharge, $B$ : Cl-Ringer (left) and SCN-Ringer (right), $C$ : distilled water, $D: 1 / 4 \mathrm{M}$ $\mathrm{NaCl}, E: 1 / 4 \mathrm{M}$ sucrose, $F: 1 / 256 \mathrm{M}$ hydrochloric quinine, $G: 1 / 64 \mathrm{~N}$ acetic acid, $H$ (left): spontaneous discharge before replacing Cl-Ringer by SCN-Ringer and $H$ (right): discharge after the replacement. Time signal: $10 \mathrm{msec}$.

sistent with the fact that anions hardly contribute to the response magnitude of gustatory receptors, but that cations determine the intensity of their response (Beidler, 1953; Fishman, 1957).

The effect of such anions as $\mathrm{Br}, \mathrm{I}, \mathrm{NO}_{3}$ and $\mathrm{SCN}$ on the membrane property of gustatory receptors appears within 30-60 minutes and both the necessary time for its occurrence and its intensity depends on the anions used. Bromide ions have the weakest action and take the longest time to induce an appreciable effect among monovalent anions, while the thiocyanate ions have the strongest action.

The common effects of these anions are: (i) the threshold of the tongue to salts is raised and its response magnitude is reduced; (ii) the threshold concentration of salt solutions for depressing water response is raised; (iii) the sensitivity of the tongue to distilled water, sucrose, quinine and acid is not very much modified as compared to the sensitivity to salts, but (iv) sooner or later the sensitivity to all kinds of taste solutions is abolished. The effectiveness of these anions may be arranged in the order of $\mathrm{SCN} \gg \mathrm{NO}_{3}>\mathrm{I}>\mathrm{Br}$, which is quite in accordance with their stimulating effectiveness, if one takes the threshold of gustatory receptors for sodium salts as an index (table 1). It is interesting to note that the depressing effectiveness of anion series on water response could be arranged in the reverse order. The anion series, $\mathrm{SCN} \gg \mathrm{NO}_{3}>\mathrm{I}>\mathrm{Br}$, in their 

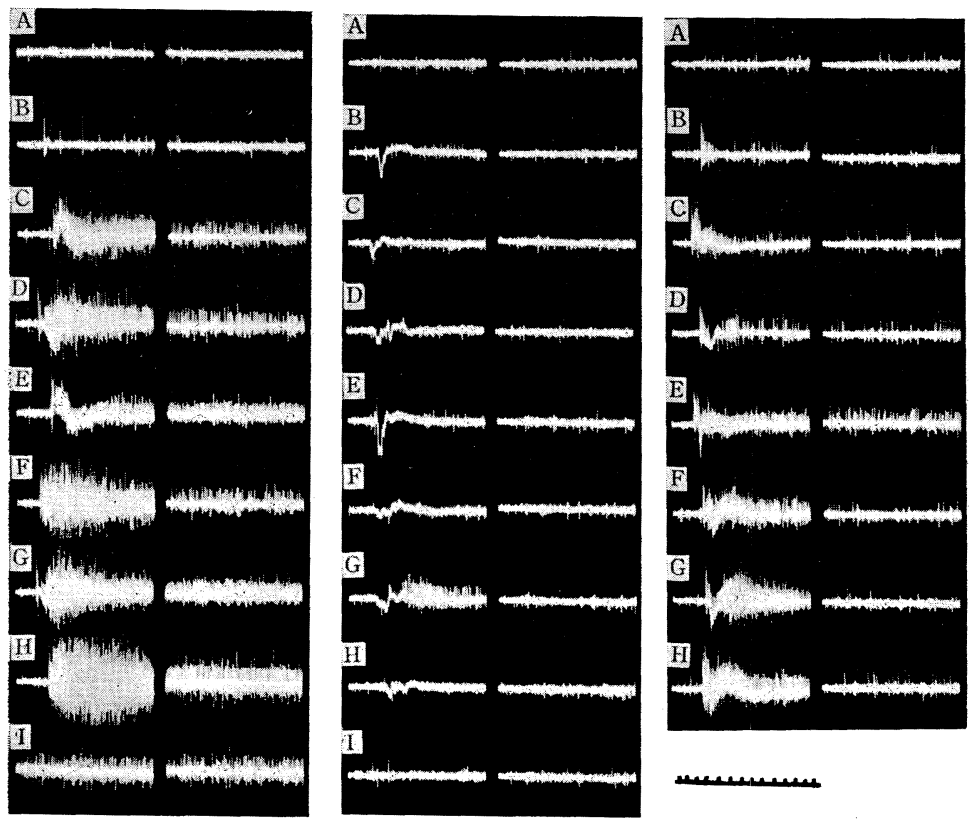

FIG. 13. Response patterns of the tongue adapted to $\mathrm{H}_{2} \mathrm{PO}_{4}$-Ringer. From left: adapted to $\mathrm{Cl}$-Ringer for $1 / 2$ hour, 1 hour after being immersed in $\mathrm{H}_{2} \mathrm{PO}_{4}$-Ringer and 1 hour after the tongue being restored to Cl-Ringer. $A$ : spontaneous discharge, $B$ : $\mathrm{Cl}$ Ringer, $C: \mathrm{H}_{2} \mathrm{PO}_{4}$-Ringer, $D$ : distilled water, $E: 1 / 2 \mathrm{M} \mathrm{NaC1}, F: 1 / 4 \mathrm{M}$ sucrose, $G: 1 / 256$ M hydrochloric quinine, $H: 1 / 64 \mathrm{~N}$ acetic acid, $I$ (left): discharge immediately after the tongue was immersed in phosphate Ringer and $I$ (middle): discharge immediately after it was restored to chloride Ringer. Time signal: $10 \mathrm{msec}$.

effectiveness of various actions on gustatory receptors are nearly the same as those found on muscle fibres, although in muscle fibres iodide is stronger than nitrate (Kahn and Sandow, 1955; Hill and Macpherson, 1954; Lubin, 1957). A far more close analogy is found in Sollner's work (1949), which points out that the rank order of the relative transference numbers, or the relative mobility of ions through membrane, of different anion species within artificial membrane which are permeable to either positively or negatively charged ions is $\mathrm{Cl}<\mathrm{Br}<$ $\mathrm{I}<\mathrm{NO}_{3} \ll \mathrm{SCN}$.

The effects of sulphate and phosphate ions are completely different from those of other monovalent anions. The existence of sulphate ions in the extracellular space of the tongue does hardly influence the activity of gustatory receptors, while phosphate ions abolish receptor activity fairly rapidly. Furthermore, their effect is completely reversible when the tongue is restored to normal Ringer, wherease it is not the case when bromide, iodide, nitrate and thiocyanate ions are employed. The last difference is particularly instructive, since it has been known that the resting and active membrane properties of muscle fibres were reversibly and readily restored when isotonic sulphate solutions immersing them were replaced by normal Ringer (Katz, 1949; Harris and Martins-Ferreira, 

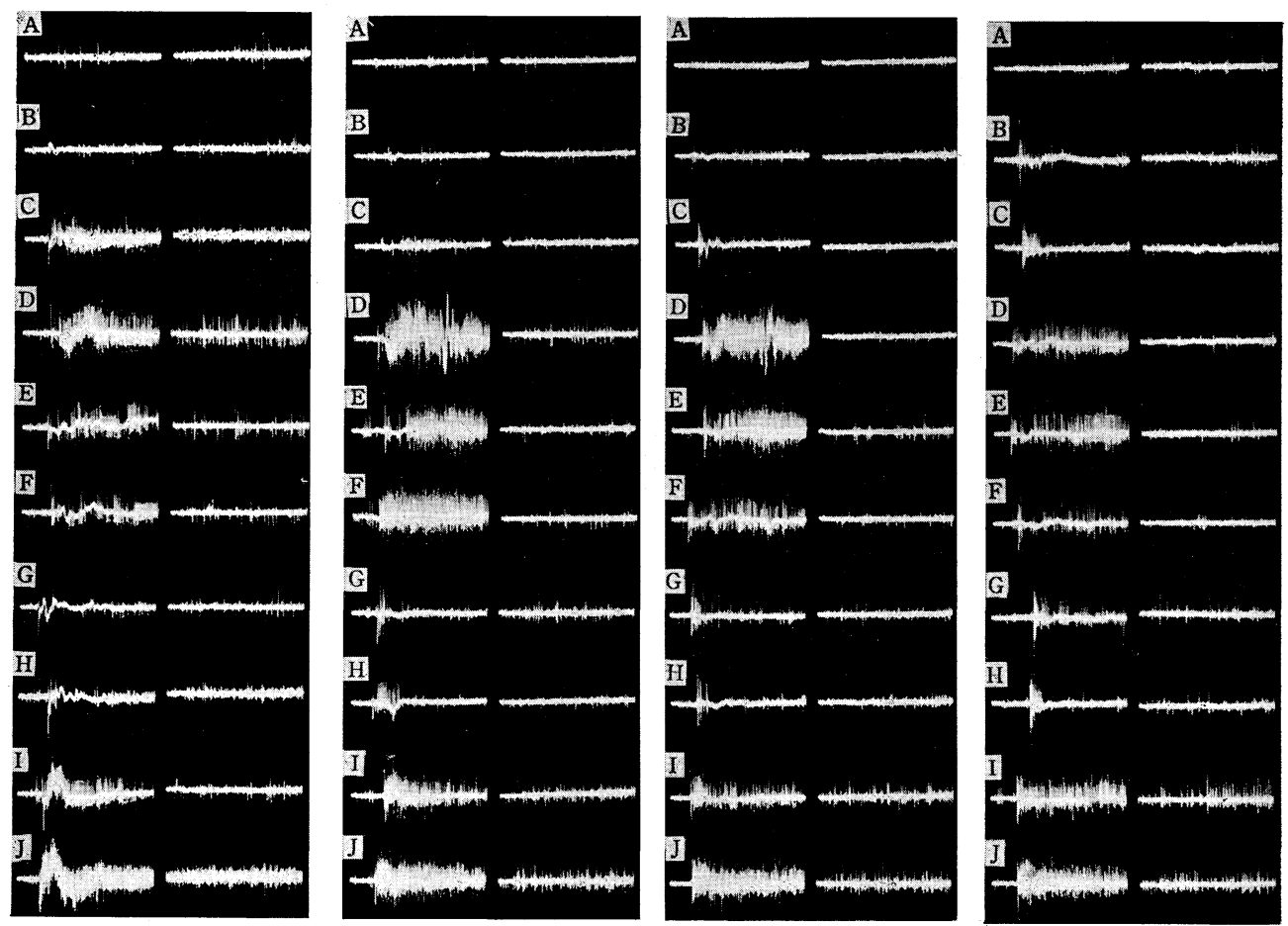

Fig. 14. Response patterns of the tongue adapted to $\mathrm{SO}_{4}$-Ringer. From left: adapted to Cl-Ringer for 30 minutes and to $\mathrm{SO}_{4}$-Ringer for 1,2 and 3 hours. $A$ : spontaneous discharge, $B$ : Cl-Ringer, $C$ : $\mathrm{SO}_{4}$-Ringer, $D$ : distilled water, $E: 1 / 1,024 \mathrm{M}$ $\mathrm{NaCl}, F: 1 / 1,024 \mathrm{M} \mathrm{Na}_{2} \mathrm{SO}_{4}, G: 1 / 64 \mathrm{M} \mathrm{NaCl}, H: 1 / 64 \mathrm{M} \mathrm{Na}_{2} \mathrm{SO}_{4}, I: 1 / 4 \mathrm{M} \mathrm{NaCl}, J: 1 / 4$ M Na $\mathrm{SO}_{4}$. Time signal: $10 \mathrm{msec}$.

1955; Hodgkin and Horowicz, 1957; Umezawa, 1957). This can be accounted for by the fact that sulphate and phosphate ions neither penetrate the muscle fibre membrane nor modify its property. From these analogous behaviour of the gustatory receptor membrane to muscle fibre membrane when they are immersed in various Ringer solutions in which $\mathrm{Cl}$ is replaced by various anions, it appears that both sulphate and phosphate ions do not penetrate the gustatory receptor membrane whereas bromide, iodide, nitrate and thiocyanate ions either penetrate it or modify its property so as to increase $\mathrm{K}$ output from the cell (Edwards et al., 1957).

The stimulating action of salts on gustatory receptors

It has been suggested in the foregoing discussion that there are some resemblances between the effect of anions on gustatory receptors and that on muscle fibres. In muscle fibres there is good evidence indicating that bromide, iodide, nitrate and thiocyanate ions decrease the permeability of the membrane for 

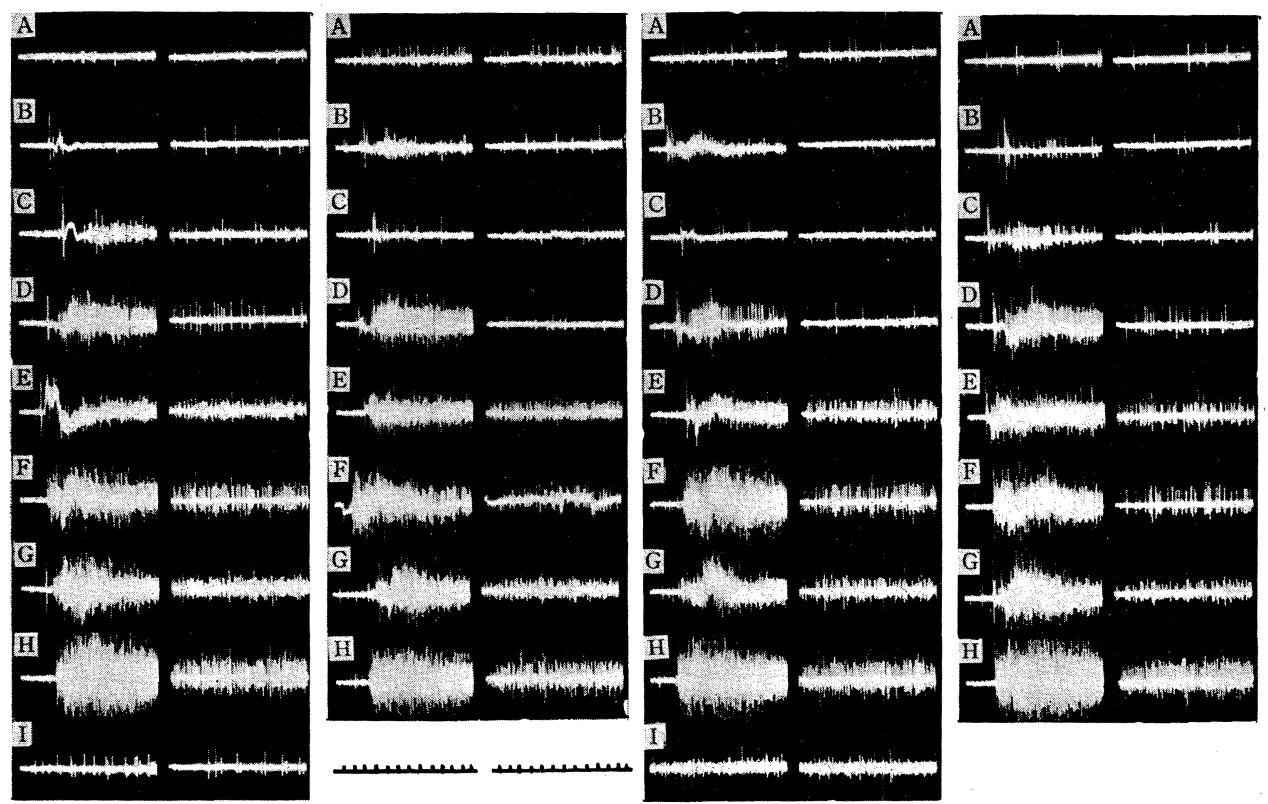

FIG. 15. Response patterns of the tongue adapted to $\mathrm{SO}_{4}$-Ringer. From left: adapted to Cl-Ringer for $1 / 2$ hour, to $\mathrm{SO}_{4}$-Ringer 1 and 2 hours and 1 hour after the tongue being restored to Cl-Ringer. $A$ : spontaneous discharge, $B: \mathrm{Cl}$-Ringer, $C$ : $\mathrm{SO}_{4-}$ Ringer, $D$ : distilled water, $E: 1 / 4 \mathrm{M} \mathrm{NaCl}, F: 1 / 4 \mathrm{M}$ sucrose, $G: 1 / 256 \mathrm{M}$ hydrochloric quinine, $H: 1 / 64 \mathrm{~N}$ acetic acid, $I$ (1st column): discharge immediately after the tongue was immersed in sulphate Ringer and $I$ (3rd column): discharge immediately after the tongue being restored to Cl-Ringer. Time: $10 \mathrm{msec}$.

potassium ions during resting and active state whereas phosphate and sulphate ions hardly affect it (Harris and Martins-Ferreira, 1955; Lubin, 1957; Padsha, 1957). In gustatory receptors, when chloride ions are substituted for one of these anions the threshold to sodium and other salts is raised and their response magnitude is reduced in the order of $\mathrm{SCN} \gg \mathrm{NO}_{3}>\mathrm{I}>\mathrm{Br}$. Considering the possibility found in the present experiment that the gustatory receptor membrane has the similar properties to the muscle fibre membrane, it is tentative to postulate that the entry of some cations into gustatory receptors might be the initial step for the initiation of gustatory impulses and that anions may modify the membrane permeability for cations. It is likely that the membrane is permeable to many kinds of cations, since most salts have stimulating action on the tongue if their concentration is sufficient, and that anions may reduce the membrane permeability for cations in the order of $\mathrm{SCN} \gg \mathrm{NO}_{3}>\mathrm{I}>\mathrm{Br}$, or alternatively the gustatory cell may lose its cellular potassium in the presence of such anions as $\mathrm{Br}, \mathrm{I}, \mathrm{NO}_{3}$ and $\mathrm{SCN}$, and consequently it shows a decrease in its response magnitude and an increase in its threshold, since Edwards et al. (1957) showed that the muscle fibre lost its potassium after being soaked in such modified anion-Ringers as containing $\mathrm{Br}, \mathrm{NO}_{3}$ or $\mathrm{SCN}$. 
The fact that the stimulating threshold of anion series can be arranged in the order of $\mathrm{NaSCN}>\mathrm{NaNO}_{3} \triangleq \mathrm{NaI}>\mathrm{NaBr}>\mathrm{NaCl}$ or $\mathrm{KNO}_{3} \triangleq \mathrm{KI}>\mathrm{KBr}>\mathrm{KCl}$ may suggest the possibility that these anions may increase the influx of cations through the membrane momentarily when these solutions are applied to the tongue, since it has been shown in muscle that thiocyanate ions increased the influx of $\mathrm{Na}$ ions (Edwards et al. 1957).

Phosphate ions have a strong stimulating action, the mechanism of which, however, may be different from that of ordinary monovalent anions, since (i) the effect of phosphate is reversible, (ii) they could not penetrate the membrane and (iii) they have a very strong stimulating action with a very low concentration, which is rather similar to $\mathrm{Mg}$ and $\mathrm{Ca}$ actions. It is attractive to speculate that phosphate ions stimulate receptors by forming a complex in or on the surface of the membrane, which will lead to the initiation of sensory impulses, and that because of the formation of a phosphate complex the membrane property is so changed that ordinary monovalent cations cannot diffuse through the membrane. On the other hand, sulphate ions neither penetrate nor influence the membrane. Therefore, $\mathrm{Na}_{2} \mathrm{SO}_{4}$ had nearly the same stimulating effect on the tongue to $\mathrm{NaCl}$ and the effect entirely depends on $\mathrm{Na}$ ions.

The stimulating mechanism of both $\mathrm{Ca}$ and $\mathrm{Mg}$ ions may essentially differs from that of common monovalent cations such as $\mathrm{Na}$ and $\mathrm{K}$, because (i) the action of $\mathrm{Ca}$ and $\mathrm{Mg}$ salts is relatively unaffected by anions when the magnitude of the response to sodium salts is already reduced and (ii) both $\mathrm{Ca}$ and $\mathrm{Mg}$ salts have little depressing action on water response. These different properties of $\mathrm{Ca}$ and $\mathrm{Mg}$ ions from monovalent cations may result from the possibility that they could not penetrate the gustatory receptor cell membrane so much as $\mathrm{Na}$ and $\mathrm{K}$ ions do. In this respect the gustatory receptor membrane has probably a similar property to the muscle or axon membrane, where $\mathrm{Ca}$ permeability is very much less than $\mathrm{K}$ and $\mathrm{Na}$ permeabilities during resting and active states (Hodgkin and Keynes, 1957). It is known that $\mathrm{Ca}$ ions react with surface membrane by forming a Ca-complex or are easily adsorbed on the surface of the biological membrane (see, for example Danielli, (1950)), and therefore the stimulating action of $\mathrm{Ca}$ and $\mathrm{Mg}$ salts may not be due to a diffusion process of $\mathrm{Ca}$ and $\mathrm{Mg}$ ions through the membrane but to binding of these ions with some negatively charged radicals on the surface of the membrane.

The depressing mechanism of water response by salts

In the preceding paper Kusano and Sato (1957) have described the possibility that water response may be initiated by an outflow of potassium ions from the interior of gustatory receptors in order to set the equilibrium condition of the membrane and that existence of some cations permeable to the membrane could depress water response by preventing the outflow of potassium ions. Since the threshold concentration of sodium salt to depress water response is raised by various monovalent anions, the effectiveness of cations to prevent potassium efflux should then be reduced. This could easily be accounted for by either of two alternative hypotheses already stated (i) that the membrane permeability to cations is reduced by the presence of such anions as $\mathrm{SCN}, \mathrm{NO}_{3}$, 
I and $\mathrm{Br}$ or (ii) that the gustatory cell loses its cellular potassium in presence of $\mathrm{SCN}, \mathrm{NO}_{3}, \mathrm{I}$ or $\mathrm{Br}$. Sulphate ions, which neither penetrate the membrane nor modify its property, have therefore no influences on the depressing effectiveness of sodium salts on water response. The observation described in the Results that the tongue, adapted to sulphate Ringer or thiocyanate Ringer, showed an increased water response after it was transferred to normal Ringer should be attributed to changes in the equilibrium condition of the membrane because of the entry of sodium ions into the cell during the period when the tongue was immersed in these solutions.

If the reaction involved in receiving common salts and in depressing water response be mainly attributed to "diffuse-in" and "diffuse-out" of cations through the gustatory receptor membrane, the necessary time for this process would be very short, probably the order of a few msec., and most of the long latency observed in salt discharge (about $50 \mathrm{msec}$., Beidler (1953); Pfaffmann (1955)) would be spent during the time from the moment, when the ionic concentration immediately outside the membrane attains to a critical level. This problem will be dealt with in the subsequent paper.

\section{The receptor mechanism for other kind of taste stimuli}

From the fact that the sensitivity of the tongue to salt solutions is much more rapidly and effectively reduced than its sensitivity to other type of taste stimuli such as sucrose, hydrochloric quinine and acetic acid when the tongue is adapted to one of the modified anion-Ringers, it may appear that the receptor mechanism for the latter kind of stimuli is entirely different from that for $\mathrm{Na}$ and $\mathrm{K}$ salts, but analogous to that for $\mathrm{Ca}$ and $\mathrm{Mg}$. Therefore in order to explain the receptor mechanism for sucrose, hydrochloric quinine and acetic acid, it may be reasonable to postulate the similar mechanism as that presented by Dethier (1956) who states "Sugar combines reversibly with receptor substances to form a complex in or as part of receptor membrane. Formation of the complex results in depolarization of the membrane, which initiates impulses in the sensory nerve."

\section{SUMMARY}

(1) The influence of various anions on activity of gustatory receptors was investigated by adapting the tongue of a frog to modified anion-Ringer, in which all $\mathrm{Cl}$ was substituted for $\mathrm{Br}, \mathrm{I}, \mathrm{NO}_{3}, \mathrm{SCN}, \mathrm{SO}_{4}$ and $\mathrm{H}_{2} \mathrm{PO}_{4}$.

(2) Immediately after exchange of normal Ringer with one of these modified anion-Ringers the response of the tongue was not appreciably changed in its threshold to various taste solutions and in its magnitude.

(3) 1-2 hours after exchange of the bathing medium the response of the tongue to salt solutions was reduced and its threshold was raised, while the threshold concentration of sodium salts to depress water response was raised. The sensitivity of the tongue to other kinds of taste stimuli was not very much modified compared with that to salts.

(4) Sooner or later all the sensitivities of the tongue to various taste stimuli 
were reduced or abolished.

(5) The effects of anions mentioned above depended on the anions used; the effectiveness was in the order of $\mathrm{SCN}>\mathrm{NO}_{3}>\mathrm{I}>\mathrm{Br}$. Sulphate had no marked effects on gustatory receptors, while their response was readily abolished in phosphate Ringer.

(6) The sensitivity of the tongue was rapidly restored when the phosphate Ringer immersing the tongue was replaced by normal Ringer, whereas the effect of other monovalent anions was irreversible.

(7) The following hypothesis was presented on the mechanism of salt reception and of the depressing action of salts on water response: Entry of cations inside gustatory receptor from the exterior is the initial step for the initiation of salt receptor activity and withdrawal of the intracellular potassium ions may initiate water response, which is prevented by exsistence of a sufficient amount of cations permeable to the membrane outside the cell. Anions reduce the permeability of the membrane to cations in the order of $\mathrm{SCN}>\mathrm{NO}_{3}>\mathrm{I}>\mathrm{Br}>\mathrm{Cl}$, or alternatively the cellular potassium reduces in the presence of $\mathrm{SCN}, \mathrm{NO}_{3}, \mathrm{I}$ or $\mathrm{Br}$.

One of the authors (M. S.) wishes to express his thankes to the Ministry of Education for the research grant defraying a part of the expense of this work. We are indebted to Prof. M. Uchida (Dept. of Biochemistry, Univ. of Kumamoto) for his kind criticism in preparing this manuscript.

\section{REFERENCES}

1. BEIDLER, L. M. Properties of chemoreceptors of tongue of rat. J. Neurophysiol. 16: 595-607, 1953.

2. COHEN, M. J., HAGIWARA, S. AND ZOTTERMAn, Y. The response spectrum of taste fibres in the cat: A single fibre analysis. Acta Physiol. Scandinav. 33: 316-332, 1955.

3. Danielli, J. F. Cell Physiology and pharmacology. New York and London: Elsevier, 1950.

4. Dethier, V. G. Chemoreceptor mechanism. Molecular structure and functional activity of nerve cells. Public. Amer. Inst. Biol. Scis. 1: 1-30, 1956.

5. EDWARDS, C., HARris, E. J. AND Nishie, KeICA. The exchange of frog muscle $\mathrm{Na}+$ and $\mathrm{K}^{+}$in the presence of the anions $\mathrm{Br}^{-}, \mathrm{NO}_{3}, \mathrm{I}$ and $\mathrm{CNS}^{-}$. J. Physiol. 135: 560-566, 1957.

6. Fishman, I. Y. Single fiber gustatory impulses in rat and hamster. J. cell. comp. Physiol. 49: 319-370, 1957.

7. HARRIS, E. J. Phosphate liberation from isolated frog muscle. J. Physiol. 122: 366370, 1953.

8. HARRIS, E. J. AND MARTINS-FERREIRA, H. Membrane potentials in the muscles of the south american frog, Leptodactylus oceatus. J. exp. Biol. 32: 539-546, 1955.

9. Hill, A. V. AND MACPherson, L. The effect of $\mathrm{NO}_{3}, \mathrm{I}$ and $\mathrm{Br}$ on the duration of the active state in the skeletal muscle. Proc. Roy. Soc. B, 143: 81-102, 1954.

10. HILl, A. V. AND How ARTH, J. V. The effect of potassium on the resting metabolism of the frog's sartorius. Proc. Roy. Soc. B. 147: 21-43, 1957.

11. Hodgkin, A. L. AND Horowicz, P. Effects of $\mathrm{K}$ and $\mathrm{Cl}$ on the membrane potential of isolated muscle fibres. J. Physiol. 137: 30-31, 1957.

12. HodGKin, A. L. AND Keynes, R. D. Movements of labelled calcium in squid giant 
axons. J. Physiol. 138: 253-281, 1957.

13. KAHN, A. J. AND SANDOW, A. Effects of bromide, nitrate and iodide on responses of skeletal muscle. Ann. N. Y. Acad. Sci. 62: 137-176, 1955.

14. KATZ, B. Les contantes electriques de la membrane du muscle. Arch. Sci. Physiol. 3: 285-300, 1949.

15. Kionka, H. And Straetz, F. Arch. exp. Path. Pharm. 95: 241-257, 1922 . quoted by Fishman 1957.

16. Kusano, K. AND Sato, M. Properties of fungiform papillae in frog's tongue. Jap. J. Physiol. 7: 324-338, 1957.

17. LUBIN, M. The effect of iodide and thiocyanate ions on the mechanical and electrical properties of frog muscle. J. cell. comp. Physiol. 49: 335-349, 1957.

18. PADShA, S. M. The influence of anions on the membrane resistance of skeletal muscle. J. Physiol. 137: 26-28, 1957.

19. Pfaffman, C. Gustatory nerve impulses in rat, cat and rabbit. J. Neurophysiol. 18: 429-440, 1955.

20. Sollner, K. The origin of bi-ionic potentials across porous membranes of high ionic selectivity. J. Phys. Chem. 53: 1211-1266, 1949.

21. UMEZAWA, S. Effect of phosphate on membrane potential and excitability of an isolated frog muscle fibre. J. Fac. Sci., Hokkaido Univ. 13: 479-483, 1957. 